Maurer School of Law: Indiana University

Digital Repository@Maurer Law

Indiana Law Journal

Volume 94 | Issue 3

Article 9

Summer 2019

\title{
Taming Sherman's Wilderness
}

Derrian Smith

Indiana University Maurer School of Law, smitderr@iu.edu

Follow this and additional works at: https://www.repository.law.indiana.edu/ilj

Part of the Antitrust and Trade Regulation Commons, Commercial Law Commons, Law and Economics Commons, and the Supreme Court of the United States Commons

\section{Recommended Citation}

Smith, Derrian (2019) "Taming Sherman's Wilderness," Indiana Law Journal: Vol. 94 : Iss. 3 , Article 9.

Available at: https://www.repository.law.indiana.edu/ilj/vol94/iss3/9

This Note is brought to you for free and open access by the Law School Journals at Digital Repository @ Maurer Law. It has been accepted for inclusion in Indiana Law Journal by an authorized editor of Digital Repository @ Maurer Law. For more information, please contact rvaughan@indiana.edu.

\section{$\Psi$}

JEROME HALL LAW LIBRARY

INDIANA UNIVERSITY

Maurer School of Law
Bloomington 


\title{
TAMING SHERMAN's WILDERNESS
}

\author{
DERRIAN SMITH*
}

INTRODUCTION .

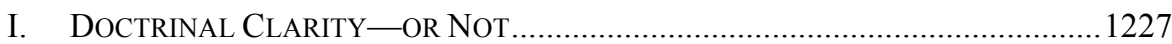

A. DEPARTURES FROM THE TEXT ……..................................................1228

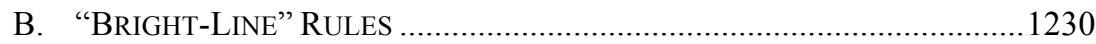

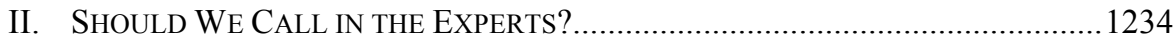

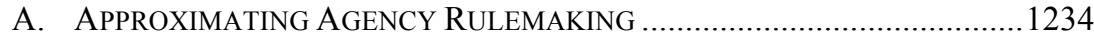

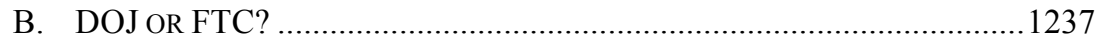

III. Constitutional OBJections to The AGEnCy SOLUtion .........................1238

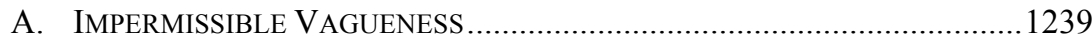

B. CONTROVERSIALITY OF ADMINISTRATIVE CRIMES .............................1241

C. UNGUIDED AGENCY AUTHORIZATIONS ................................................... 1242

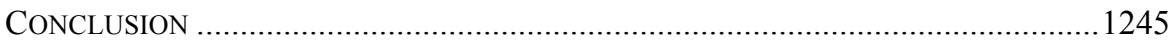

\section{INTRODUCTION}

It is easy to get lost. Law students enrolled in introductory antitrust courses know this well. Apparently, so does the judiciary. A broad "charter of freedom" - the "Magna Carta of free enterprise" - the Sherman Act prohibits "every contract, combination ... or conspiracy ... in restraint of trade," and condemns "every person who shall monopolize" any commercial market. ${ }^{3}$ In that single legislative stroke more than a century ago, Congress both attended to public outcry over ravaging cartels and sent the judiciary on an expedition into the "wilds of economic theory.",

There is little doubt that Congress intended economic regulation under the Sherman Act to develop with flexibility—case-by-case, claim-by-claim. ${ }^{5}$ Yet, given

* J.D., 2019, Indiana University Maurer School of Law; B.A., 2016, Indiana University - Indianapolis. Foremost thanks to my wife, Mariana Lopez-Owens, for her patient and unending support. Very special thanks also to Professor Shana Wallace for helpful feedback and invaluable mentorship. Finally, gratitude to Professor Dawn Johnsen and the hardworking staff of the Indiana Law Journal.

1. United States v. Socony-Vacuum Oil Co., 310 U.S. 150, 221 (1940).

2. United States v. Topco Assocs., 405 U.S. 596, 610 (1972); Appalachian Coals, Inc. v. United States, 288 U.S. 344, 359 (1933); see also Christopher R. Leslie, Antitrust Law as Public Interest Law, 2 U.C. IRVINE L. REV. 885, 886 (2012) ("The Sherman Act of 1890 is the foundational statute of federal antitrust law.").

3. 15 U.S.C. $\S \S 1-2(2012)$.

4. Topco, 405 U.S. at 609 n.10; see Leslie, supra note 2, at 888.

5. See Leegin Creative Leather Prods., Inc. v. PSKS, Inc., 551 U.S. 877, 899 (2007) ("From the beginning the Court has treated the Sherman Act as a common-law statute."); see also 2 Phillip E. AReEda \& Herbert HovenKamp, Antitrust Law 1 301, at 5-7, (4th ed. 2014); William F. Baxter, Separation of Powers, Prosecutorial Discretion, and the "Common Law" Nature of Antitrust Law, 60 TEX. L. REV. 661, 661-63 (1982) (arguing that to afford flexibility, "Congress adopted what is in essence enabling legislation that has permitted a common-law refinement of antitrust law through an evolution guided by only the most general 
the unusual level of interpretation the Act requires, the effort of supplying the content of it's sweeping prohibitions often bears closer resemblance to formulating policy than to deciphering text. ${ }^{6}$ The result, in the words of Richard Posner, is that the judiciary has "made antitrust law out of the cryptic antiquated language of the Sherman Act.",

Perhaps more than ever, the vagueness of the Sherman Act's text needs a remedy that a century's worth of judicial gloss has failed to provide. Reliance on the customary techniques of judicial reasoning may now make less sense; ${ }^{8}$ the modernization of our economy demands a modernized antitrust regime. ${ }^{9}$ Decided upon more than one hundred years ago, the primarily post-hoc, increasingly factintensive adjudicative approach sent the judiciary roving through the complexities of competition economics with far less than a statutory Polaris. ${ }^{10}$ And after a centuryplus long foray into the complexities of economic competition, it is even possible that the judiciary has plunged into the "sea of unconstitutionality.", 11

statutory directions").

6. See Richard A. Posner, Divergent Paths: The Academy and the Judiciary 104 (2016).

7. Id. at 107 (emphasis added). Of course, the Sherman Act has been supplemented by other statutes-notably, "the equally cryptic Clayton Act." Id.; see also AREEDA \& HOVENKAMP, supra note 5, 1301 , at 6-7. "[T] he use of unelaborated common law words and references seems simply to have invested the federal courts with a new jurisdiction." AREEDA \& HovenKAMP, supra note $5, \uparrow 301$, at 6 . On one hand, "the Sherman Act . . could be taken as a legislative indication of the proper direction." On the other hand, the Act "may be seen not as a prohibition of any specific conduct but as a general authority to do what common law courts usually do." Id. ๆ 301, at 6-7.

8. AREEDa \& HovenKamp, supra note $5, \uparrow 306$, at 81 (observing that "judges may sometimes be quite far at sea" with such economic concepts as "anticompetitive harm, procompetitive redeeming virtues, and less restrictive alternatives"); ROBERT H. BORK, THE Antitrust Paradox: A Policy at War with Itself 36 (The Free Press 1993) (1978) (arguing that the Sherman Act's evolution is "controlled by the progress of economic understanding"); Daniel A. Crane, Technocracy and Antitrust, 86 Tex. L. Rev. 1159, 1160 (2008) [hereinafter Crane, Technocracy] (arguing that antitrust's technocratic shift should continue).

9. See generally Rebecca Haw, Amicus Briefs and the Sherman Act: Why Antitrust Needs a New Deal, 89 TEX. L. Rev. 1247 (2011); see also BoRK, supra note 8, at 81. In Bork's estimation, "the problem that arises when antitrust adjudication attempts to reconcile inconsistent values on a case-by-case basis should be enough to indicate the impropriety of courts undertaking such a function." BORK, supra note 8 , at 81 .

10. Herbert Hovenkamp, Principles of Antitrust 34 (2017) (“[T]he Sherman Act condemns 'every contract, combination ... or conspiracy in restraint of trade,' or every person who shall 'monopolize,' without giving a clue about what those phrases mean."); Robert H. Bork, Legislative Intent and the Policy of the Sherman Act, 9 J.L. \& ECON. 7, 48 (1966) ("In terms of 'law' ... the Sherman Act tells judges very little.").

11. Andrew S. Oldham, Sherman's March (In)to the Sea, 74 Tenn. L. Rev. 319, 325 (2007). Judge Oldham contends that the modern-day scope of the Sherman Act has entered the realm of unconstitutionality in part because the judiciary has misguidedly interpreted the Act such that "judges can and should create substantive rules without legislative guidance." $I d$. In Judge Oldham's view, this interpretation has "unmoored the Sherman Act from its statutory foundations." Id.; see also infra Part III. 
Of course, the fact that the Supreme Court retains ultimate interpretive authority does not make the judiciary a lone adventurer. ${ }^{12}$ Enforcement agencies must also navigate the economic landscape to give content to the Act's prohibitions. ${ }^{13}$ Not only does the text of the Act grant the judiciary largely unfettered interpretive leeway, it also affords enforcers unsettling discretion to determine whether conduct deserves criminal penalties ${ }^{14}$ or civil remedies. ${ }^{15}$ But given that the judiciary is generally comprised of high-level generalists rather than technology-forward economic experts, the judiciary may no longer be best equipped to play the leading role. ${ }^{16}$ The judiciary is certainly apt to reason by way of analogy and precedent, but interpretation of the Sherman Act requires that adjudicators and norm-creators maintain an updated comprehension of prevailing economic theory and modern business practices. ${ }^{17}$ Faced with emergent technologies and business models that

12. See Oldham, supra note 11 , at 320 .

13. See BorK, supra note 8, at 36 ("Precedent is not ultimately controlling; economic argument is."). The DOJ and the FTC offer economic arguments in a myriad of Sherman Actrelated litigation. See, e.g., U.S. DeP'T of Justice, ANTITRUST Division WorkLOAD StaTiSTICS FY 2008-2017, https://www.justice.gv/atr/fi;e/788426/download [https://perma .cc/R4TC-TDXG]; Fed. TRAdE Comm'N, Anticompetitive Practices, https://www.ftc.gov /enforcement/anticompetitive-practices [https://perma.cc/WKS9-V4KN].

14. The Act's significantly enhanced criminal penalties loom over imprudent corporate executives. See 15 U.S.C. $\S \S 1-2$ (2012). A violation committed by a corporation is punishable by up to a $\$ 100,000,000$ fine. $I d$. Individuals can be fined $\$ 1,000,000$, imprisoned up to 10 years, or both. Id.; see also U.S. DeP'T OF Justice, SHERMAN Act Violations Yielding A CORPorate Fine of $\$ 10$ Million or More (last updated June 13, 2018), https:// www.justice.gov/atr/sherman-act-violations-yielding-corporate-fine-10-million-or-more [https://perma.cc/8KFW-B2FY].

15. See U.S. Dep't of Justice, Organization, Mission and Functions Manual: CRIMINAL DIVISION, https://www.justice.gov/jmd/organization-mission-and-functions -manual-criminal-division [https://perma.cc/DW8Z-RQWU] (last updated Aug. 31, 2018); see also U.S. Dep't of Justice Antitrust Division \& Fed. Trade Comm'N, Antitrust Guidance for Human Resource Professionals (2016) [hereinafter No-Poach Guidance]; Karen L. Corman, Karen Hoffman Lent \& Tara L. Reinhart, Shifting Enforcement of NoPoaching Agreements, SKADDEN (Apr. 25, 2018), https://www.skadden.com/insights /publications/2018/04/quarterly-insights/shifting-enforcement-of-nopoaching-agreements.

16. See Michael R. Baye \& Joshua D. Wright, Is Antitrust Too Complicated for Generalist Judges? The Impact of Economic Complexity and Judicial Training on Appeals, 54 J. L. \& ECON. 1, 3 (2011); Haw, supra note 9, at 1248; C. Scott Hemphill, An Aggregate Approach to Antitrust: Using New Data and Rulemaking to Preserve Drug Competition, 108 Colum. L. Rev. 629, 630 (2009) ("Unfortunately, courts lack the information needed to select optimal rules .... In selecting an antitrust decisionmaker, moreover, we ought to favor the institution that has superior access to aggregate information . . . ."); see also Alex Lipton, Supreme Court Justices Just Don't Understand Tech, SHAKE (June 25, 2014), http://www .shakelaw.com/blog/supreme-court-judges-tech/ [https://perma.cc/NZG8-RPVW]; Casey C. Sullivan, Judges Know Nothing About Technology, Judge Says, FindLaw: TeChnologist (July 31, 2015, 10:58 AM), https://blogs.findlaw.com/technologist/2015/07/judges-know -nothing-about-technology-judge-says.html [https://perma.cc/QDB5-4HFA].

17. See Haw, supra note 9, at 1248; Christopher R. Leslie, Rationality Analysis in Antitrust, 158 U. PENN L. Rev. 261, 286 ("Judges do not necessarily understand how businesses operate, and most judges are unfamiliar with the full sweep of the relevant economics literature ....”). 
lend themselves to increased market concentration, ${ }^{18}$ the regulatory task increasingly demands enlightened, data-driven analysis. ${ }^{19}$ And against the judiciary's lack of economic expertise, the input of expert witnesses and third-party industry stakeholders have come to play an important role in the adjudication of Sherman Act cases. $^{20}$

Yet, even as ideas that were once indubitable have become the subjects of open debate, ${ }^{21}$ none of this is to say that the Act should be tossed out entirely. An updated enforcement approach need not completely abandon traditional principles. ${ }^{22}$ Shifts in the regulatory landscape over the past several decades are likely indications that the wilds have been tamed in significant ways. ${ }^{23}$ Still, the combination of a widespread decline in competition, ${ }^{24}$ disagreement over fundamental antitrust

18. See Lina M. Khan, Sources of Tech Platform Power, 2 Geo. L. Tech. Rev. 325, 325 (2018) [hereinafter Platform Power] ("A handful of tech platforms mediate a large and growing share of our commerce and communications."); see also COUNCIL OF ECON. Advisors, Benefits of Competition And IndicAtors of MARKet Power (2016); Paula Dwyer, Should America's Tech Giants Be Broken Up?, BloOMBERg Businessweek (July 20, 2017, 4:00 AM), https://www.bloomberg.com/news/articles/2017-07-20/should-america-s -tech-giants-be-broken-up; Too Much of a Good Thing, ECONOMIST (Mar. 26, 2016), https:// www.economist.com/news/briefing/21695385-profits-are-too-high-america-needs-giant -dose-competition-too-much-good-thing [https://perma.cc/998Y-PULR].

19. Haw, supra note 9, at 1248.

20. Id. at 1248, 1287; see also Daniel A. Crane, Rules Versus Standards in Antitrust Adjudication, 64 WASH. \& LEE L. REV. 49, 50 (2007) [hereinafter Crane, Rules Versus Standards] ("Once the stars of the antitrust courtroom, lawyers now play the supporting cast to economists."); Jesse Eisinger \& Justin Elliot, These Professors Make More Than a Thousand Bucks an Hour Peddling Mega-Mergers, ProPublica (Nov. 16, 2016), https://www.propublica.org/article/these-professors-make-more-than-thousand-bucks-hour -peddling-mega-mergers [https://perma.cc/F6PS-DH6N] ("Today, lawyers still write the briefs, make the arguments and conduct the trials, but the core arguments are over economists' models ...."). In fact, the DOJ and FTC even participate as amici in litigation between private parties. See, e.g., Brief for the United States as Amicus Curiae, Apple Inc. v. Pepper, $138 \mathrm{~S}$. Ct. 2647 (cert. granted June 18, 2018) (No. 17-204), 2018 WL 2131602.

21. David Streitfeld, Amazon's Antitrust Antagonist Has a Breakthrough Idea, N.Y. TiMES (Sept. 7, 2018), https://www.nytimes.com/2018/09/07/technology/monopoly-antitrust -lina-khan-amazon.html [https://perma.cc/B423-JK4V].

22. See, e.g., Senate Democrats, A Better Deal: Cracking Down on Corporate MonOPOLIES (2017), https://www.democrats.senate.gov/imo/media/doc/2017/07/A-Better -Deal-on-Competition-and-Costs-1.pdf [https://perma.cc/T7AM-DELU]; Hearings on Competition and Consumer Protection in the 21st Century, Fed. TRAde Comm'N, https://www.ftc.gov/policy/hearings-competition-consumer-protection [https://perma.cc /WKF3-LFWC].

23. Crane, Rules Versus Standards, supra note 20, at 50 ("The wilds are being tamed.").

24. See, e.g., Lina M. Khan, The Ideological Roots of America's Market Power Problem, 127 YALE L.J. F. 960, 960-61 (2018), https://www.yalelawjournal.org/forum/the-ideological -roots-of-americas-market-power-problem [https://perma.cc/4PZ9-G9KM]. 
philosophies, ${ }^{25}$ and swells of public and political fervor ${ }^{26}$ demands that Congress do what it did in 1890: update antitrust's policy-making approach. ${ }^{27}$ An additional step toward taming the wilds - toward optimizing clarity, predictability, and outcomes - might be to shift the task of interpreting the Sherman Act to an antitrust agency. ${ }^{28}$

This Note proceeds in four Parts. Part I outlines the interpretive difficulties spawned by the vagueness of the Sherman Act-particularly, the judiciary's necessary but undeniable departures from the text of the statute and the resulting doctrinal confusion. Part II considers ways in which the judiciary's decision-making in Sherman Act cases approximates agency rulemaking and whether it makes sense to delegate interpretive authority to an antitrust agency. Yet, while the agency solution has upside, it would not easily escape criticisms that the Act does not provide sufficient notice of the conduct it proscribes and that the Act is an impermissible delegation of legislative authority. ${ }^{29}$ Part III examines these two hurdles, taking stock of separation of powers and void-for-vagueness principles. Part IV concludes.

\section{DOCTRINAL CLARITY—OR NOT}

It has always been true that Sherman Act cases are too complex for the judiciary to resolve with strict adherence to a literal reading of the text. ${ }^{30}$ Because the text itself provides little direction, the judiciary has spent more than a century smoothing a "judicial gloss" over the Sherman Act's Constitution-like language. ${ }^{31}$ When the judiciary updates Sherman Act common law with new insights, it acts, therefore, much like a legislative body. ${ }^{32}$ Having spent years attempting to craft bright-line

25. Id. at 964 ("The enfeebled state of antitrust enforcement traces directly to an intellectual movement that fundamentally rewrote antitrust law-redefining its purpose, its orientation, and the values that underlie it.").

26. Id. at 962, 963; see also Alexei Alexis, 'Hipster Antitrust' Comes Under Senate Spotlight, BloOMBeRG LAw (Dec. 13, 2017), https://www.bna.com/hipster-antitrust-comes -n73014473208 [https://perma.cc/9KAP-U7F9].

27. See generally Lina M. Khan, Amazon's Antitrust Paradox, 126 YALE L.J. 710 (2017); see also Comment of Fed. Trade Comm'r Rohit Chopra, Hearing \#1 on Competition and Consumer Protection in the 21st Century (Sept. 6, 2018), https://www.ftc.gov/system /files/documents/public_statements/1408196/chopra_-_comment_to_hearing_1_9-6-18.pdf [https://perma.cc/X9MQ-83QB].

28. See, e.g., Haw, supra note 9, at 1249 (proposing a delegation of interpretive authority to the FTC); see also Comment of Fed. Trade Comm'r Rohit Chopra, supra note 27.

29. See Oldham, supra note 11, at 324; see also Emilie F. Athanasoulis, Note, Is the Sherman Act Unconstitutionally Vague as a Criminal Statute? A Re-evaluation After Gypsum, 13 SufFolk U. L. Rev. 1284, 1289 (1979).

30. See Crane, Rules Versus Standards, supra note 20, at 51 ("[A]ntitrust cases are too complex and socially important to turn on simplistic legal commands.")

31. See Continental T.V., Inc. v. GTE Sylvania Inc., 433 U.S. 36, 49 (1977); Appalachian Coals v. United States, 288 U.S. 344, 359 (1933); Albert H. WAlkeR, History OF THE SHerman Law of the United States of America 47 (1910) ("The Sherman Law . . . was like the Constitution ... in that it was expressed in brief, broad and comprehensive language, requiring some judicial construction and many diversified applications to different cases for its practical development into generally recognized law."); see also BORK, supra note 8, at 36 ("[T]he Sherman Act [is] not a set of specific rules, still less a body of precedent ....").

32. See Baxter, supra note 5, at 672; Oldham, supra note 11, at 324. 
rules and standards, courts are fully aware that without such guideposts "businessmen would be left with little to aid them in predicting in any particular case what courts will find to be legal and illegal under the Sherman Act." 33 But brightline rules have not proven to be the most effective tools. ${ }^{34}$ This Part highlights some of the doctrinal and interpretive difficulties spawned by the Act's sparse guidance.

\section{A. Departures from the Text}

Generally speaking, Sherman Act section 1 doctrine has been defined by two purportedly distinct rules: the per se rule and the rule of reason. ${ }^{35}$ Conduct such as naked price fixing, market allocation, and group boycotting is considered irredeemably anticompetive. ${ }^{36}$ That is, the judiciary has decided that such conduct so consistently restrains trade that it violates section 1 regardless of circumstance. ${ }^{37}$ To successfully prove that a defendant committed a per se violation, plaintiffs theoretically need only show that the conduct occurred. ${ }^{38}$ On the other hand, some conduct could be considered beneficial to competition in light of extant market conditions and other surrounding circumstances. Under the rule of reason, plaintiffs must show that the conduct had an anticompetitive effect and that such effects outweigh any of the conduct's procompetitive benefits. ${ }^{39}$ These two rules illustrate the judiciary's basic interpretation of the Sherman Act: the Act only prohibits unreasonable conduct that harms competition more than it promotes competition. ${ }^{40}$ Whereas per se illegal conduct is characterized by its inherently unreasonable character, the rule of reason allows defendants to cast their behavior in the best possible light. $^{41}$

The judiciary's reliance on measures of reasonableness represents its first major departure from the text of the statute. To reiterate, the Sherman Act prohibits "every

33. United States v. Topco Assocs., 405 U.S. 596, 609 n.10 (1972).

34. See Crane, Rules Versus Standards, supra note 20, at 55 ("[Antitrust law] governs too vast and too complex an array of business practices to be reduced to a handful of categorical rules."); Matthew G. Sipe, The Sherman Act and Avoiding Void-for-Vagueness, 45 FLA. ST. U. L. REV. 709, 761 (2018) (arguing that the "deficiencies of the [Sherman Act's] text" have resulted in "judicially-created rules that tolerate and maintain ambiguity"); Maurice E. Stucke, Does the Rule of Reason Violate the Rule of Law?, 42 U.C. DAVIS L. REV. 1375, 1378 (2009).

35. Stucke, supra note 34, at 1378 ("In determining the legality of restraints of trade, the Supreme Court generally employs either a per se or rule-of-reason standard."); see also Oldham, supra note 11 , at 320.

36. See Price Fixing, Bid Rigging, and Market Allocation Schemes: What They Are and What to Look For, U.S. DEP'T OF JUSTICE, https:/www.justice.gov/atr/price-fixing-bid -rigging-and-market-allocation-schemes [https://perma.cc/C3HH-U3RR] (last updated June 25, 2015).

37. HovenKAMP, supra note 10, at 233 ("The per se rule says that once we know a certain amount about a practice we can pass judgment on its legality without further inquiry."); see also, e.g., N. Pac. Ry. Co. v. United States, 356 U.S. 1, 5 (1958) (summarizing the per se rule).

38. E.g., HovENKAMP, supra note 10, at 233.

39. See, e.g., Bd. of Trade of Chi. v. United States, 246 U.S 231, 238 (1918) (summarizing the rule of reason); AREEDA \& HovENKAMP, supra note 5, ๆ 305, at 62-63.

40. AREEDA \& HOVENKAMP, supra note 5, \ 305, at 62-63.

41. Id. 
... combination . . . in restraint of trade." 42 The plain reading of that language was rejected early on when the judiciary reasoned instead that not every conceivable contract or combination is prohibited by the Act-only those that unreasonably restrain trade are prohibited. ${ }^{43}$ From the standpoint of logic and policy, this interpretation is undoubtedly desirable. ${ }^{44}$ Indeed, the function of all contracts is to restrain trade, and every market requires some degree of cooperation among those who might otherwise be competitors. ${ }^{45}$ This interpretation is not, however, grounded in a strictly plain reading of the text.

Another major departure from the statute's text occurred later on with the Supreme Court's decision in United States v. United States Gypsum Co. ${ }^{46} \mathrm{Keep}$ in mind: in terms of criminal liability the Sherman Act provides that "[e]very person who shall make any contract or engage in any combination or conspiracy hereby declared to be illegal shall be deemed guilty of a felony." 47 The Gypsum defendants faced criminal sanctions under this provision for engaging in a per se illegal pricefixing scheme. ${ }^{48}$ The Court admitted that " $[\mathrm{t}]$ he Sherman Act, unlike most traditional criminal statutes, does not . . precisely identify the conduct which it proscribes[,]" creating the possibility that even acts committed without criminal intent could lead to criminal liability. ${ }^{49}$ Then, without any textual reference to state of mind or intent, the Court held that criminal liability cannot be rendered under the Sherman Act unless the defendant possesses "knowledge of [the] probable consequences" of her conduct. ${ }^{50}$ Unlike other federal criminal statutes, the Sherman Act's mens rea requirement is the product not of careful legislation, but of unavoidable judicial reasoning. 51

42. 15 U.S.C. $\S 1$ (2012) (emphasis added).

43. Bd. of Trade of Chi., 246 U.S. at 238; Standard Oil Co. v. United States, 221 U.S. 1, 62-65 (1911); Robert Connolly, The Sherman Act is Unconstitutional as a Criminal Statute: (Part 1), CARTEL CAPERS (July 6, 2017), http://cartelcapers.com/blog/sherman-act -unconstitutional-criminal-statute-part-1/\#_ftnref [https://perma.cc/C7XH-PMUG] ("[T]he first Supreme Court triage on the Sherman Act was that only 'unreasonable restraints' of trade were prohibited. But, that doesn't clear things up too much - What is an unreasonable restraint of trade?" (footnote omitted)); see also N. Pac. Ry. Co. v. United States, 356 U.S. 1, 5 (1958) ("Although [the Sherman Act's] prohibition is literally all-encompassing, the courts have construed it as precluding only those contracts or combinations which 'unreasonably' restrain competition." (citations omitted)); Baxter, supra note 5, at 668.

44. See, e.g., Nat'l Soc'y Prof. Eng'rs v. United States, 435 U.S. 679, 688 (1978) (explaining that if "read literally, $\S 1$ would outlaw the entire body of private contract law," which is a body of law that "enables competitive markets ... to function effectively").

45. Id. ("One problem presented by the language of $\S 1$ of the Sherman Act is that it cannot mean what it says. The statute says that 'every' contract that restrains trade is unlawful. But ... restraint is the very essence of every contract."); Leslie supra note 2, at 890 ("[T] text of Section 1 risks invalidating all contracts because every contract restrains trade in some way."); see also Frank H. Easterbrook, The Limits of Antitrust, 63 TEX. L. Rev. 1, 1, 3 (1984).

46. 438 U.S. 422 (1978).

47. 15 U.S.C. $\$ 1$ (2012).

48. See Gypsum, 438 U.S. at 438.

49. Id.

50. Id. at 444. Prescribing such a prohibition on criminal intent is typically considered the job of the legislature. See infra Part III.

51. See generally 18 U.S.C. $\S \S 32-2721$ (codifying federal crimes). 


\section{B. "Bright-Line” Rules}

Again, the Court's departures from the text of the statute can be characterized as practical responses to the difficulties of impracticable language. Commerce would surely be stifled if every contract in restraint of trade were made illegal, and much procompetitive conduct might be discouraged if even well-intentioned behavior triggered criminal sanctions. ${ }^{52}$ But while the initial major departure involved what was an apparently clean distinction between two categories of conduct, the dichotomous per se versus rule of reason schema has gradually become less than clear. $^{53}$

The shift away from clean categories has most likely been impelled by the increased difficulty and complexity of Sherman Act cases. ${ }^{54}$ Indeed, the Court has admitted that "our categories of analysis of anticompetitive effect are less fixed than terms like 'per se' . . and 'rule of reason' tend to make them appear." ${ }^{, 55}$ Nor does the Court deny that "there is often no bright line separating per se from [r]ule of [r]eason analysis." ${ }^{, 56}$ In the Court's estimation, "[p]er se rules may require considerable inquiry into market conditions before the evidence justifies a presumption of anticompetitive conduct." ${ }^{, 57}$ And as the economy continues to modernize, the judiciary considers fewer and fewer behaviors appropriate for analysis under the per se rule. ${ }^{58}$

In Dr. Miles Medical Co. v. John D. Park \& Sons, for example, the Court held that minimum resale price maintenance (RPM) was a per se violation of the Sherman Act. ${ }^{59}$ Several decades later, exposed to new economic theories, the Court changed its mind about RPM. It held in Leegin Creative Leather Products, Inc. v. PSKS, Inc.

52. See AREEDA \& HovenKAMP, supra note 5, ๆ 303, at 44. But see Nash v. United States, 229 U.S. 373, 377 (1913) (upholding the constitutionality of the Sherman Act's vague text in light of defendant's argument that "estimates may differ" as to the Act's meaning, and that, therefore, "a man might find himself in prison because his honest judgment did not anticipate that of a jury of less competent men").

53. Crane, Rules Versus Standards, supra note 20, at 58, 67.

54. See id. at 55 ("Antitrust law ... governs too vast and complex an array business practices to be reduced to a handful of categorical rules."); Easterbrook, supra note 45, at 5 ("The practices that come before the courts today are more complex . . . and the questions are more difficult.").

55. Cal. Dental Ass'n v. FTC, 526 U.S. 756, 779 (1999) (emphasis omitted).

56. NCAA v. Bd. of Regents of the Univ. of Okla., 468 U.S. 85, 104 n.26 (1984) (emphasis omitted).

57. NCAA, 468 U.S. at 104, n.26.

58. See Abbot B. Lipsky, Antitrust Economics-Making Progress, Avoiding Regression, 12 GeO. MASON L. REV. 163 (2003) (observing that "the upsurge of antitrust economics has gone hand-in-hand with the abandonment of most per se rules"); Crane, Rules Versus Standards, supra note 20, at 84 (describing "the growing inclination toward fulsome review of the facts" and the growing inclination of courts to "reject bright-line rules"); Easterbrook, supra note 45 , at 7 .

59. 220 U.S. 373, 409 (1911). The term "resale price maintenance" describes an agreement between a supplier and a retailer in which the retailer agrees not to discount a product's retail price below the level set by the supplier. 
that RPM may carry procompetitive benefits in some situations and should therefore be analyzed under the rule of reason, rather than under the per se rule. ${ }^{60}$

In addition to RPM, the list of conduct once considered appropriate for strict per se analysis-but no longer considered as such-includes maximum price maintenance, ${ }^{61}$ non-price vertical restraints, ${ }^{62}$ and even some forms of horizontal restraints. For instance, while tying has traditionally been considered per se illegal, it is typically analyzed under a rule that is "per se" in name only. ${ }^{63}$ In Broadcast Music, Inc. v. CBS, Inc., the court declined to apply per se analysis to a blanket licensing arrangement that facilitated a fix on prices. ${ }^{64}$ In NCAA v. Board of Regents of the University of Oklahoma, the Court declined to apply the per se rule to the NCAA's limitation on televising college football games, even though the limitation fixed price and restricted output. ${ }^{65}$ The thing to take away from these cases is that although price fixing and other quintessential per se violations were once considered unquestionably anticompetitive, quintessentially anticompetitive behavior may be permitted if it is found to be economically efficient or beneficial. ${ }^{66}$

But it's not just the deterioration of the per se rule that fosters confusion. Even the rule of reason does not provide significant clarity or predictability. In Ohio v. American Express Co., the Court followed an unprecedented application of the rule of reason by inserting the concept of two-sided markets. ${ }^{67}$ The Court held that where a firm, such as a credit card company, serves different sets of customers in distinct but interrelated sides of a market, such as cardholders and merchants, plaintiffs must show that the defendant's conduct had anticompetitive effects in both sides of the market. ${ }^{68}$ But prior to the Court's ruling in American Express, it had been generally understood that markets should be defined narrowly. The Court had explained in Times-Picayune Publishing Co. v. United States that even if a firm serves two sides of a market, the analysis should be carefully focused on the side of the market that

60. 551 U.S. 877,894 (2007).

61. Compare Albrecht v. Herald Co., 390 U.S. 145 (1968), with State Oil v. Khan, 522 U.S. 3 (1997).

62. Compare United States v. Arnold, Schwinn \& Co., 388 U.S. 365 (1967), with Continental T.V., Inc. v. GTE Sylvania Inc., 433 U.S. 36 (1977).

63. HovenKAMP, supra note 10, at 406-08 (explaining that "the so-called per se rule applied to tying arrangements is idiosyncratic" because it requires "proof of market power" and allows defendants to "offer various defenses"). Compare United States v. N. Pac. Ry. Co., 356 U.S. 1 (1958) (declaring that tying is appropriate for per se analysis), with Jefferson Parish Hosp. Dist. v. Hyde, 466 U.S. 2 (1984) (declining to apply per se analysis to a hospital's tiein of anesthesiological services). See also, e.g., United States v. Microsoft Corp., 253 F.3d 34 (D.C. Cir. 2001 (applying rule of reason analysis to a tie-in executed as a bundled discount).

64. Broadcast Music, Inc. v. CBS, Inc., 441 U.S. 1, 23, 24 (1979) ("[W]e have some doubt - enough to counsel against application of the per se rule_-about the extent to which [issuance of blanket licenses] threatens . . . competitive pricing . . . . we cannot agree that it should automatically be declared illegal ....").

65. NCAA v. Bd. of Regents of the Univ. of Okla., 468 U.S. 85, 100 (1984).

66. See, e.g., id.

67. 138 S. Ct. 2274 (2018). Cf. Times-Picayune Pub. Co. v. United States, 345 U.S. 594 (1953) (examining the market for newspaper readers independently from the interrelated market for newspaper advertising space).

68. See Am. Express, 138 S. Ct. at 2286-88. 
was harmed by the anticompetitive conduct. ${ }^{69}$ This is exactly what the Court declined to do in American Express, even though nearly all markets can be understood as twosided. $^{70}$ The Court's adoption of a two-sided market theory is a slippery slope that may allow firms to demonstrate the reasonableness of their anticompetitive conduct if they can show that it only harmed one side of a two-sided market. ${ }^{71}$

Beyond the doctrinal confusion it causes, confusion over the rules' inner and outer contours has been experienced by firms in the form of increased litigation costs. ${ }^{72}$ The value of the per se rule is attributable in part to the prelitigation cost savings generated by its simplicity: less to prove means less discovery, which limits parties' expenses and conserves judicial resources. ${ }^{73}$ Indeed, as the Court has observed, the per se rule "avoids the necessity for an incredibly complicated and prolonged economic investigation into the entire history of the industr[ies] involved" just to figure out whether particular conduct caused unreasonable harm to competition. ${ }^{74}$ But when everything is relevant, as it is under the rule of reason, the disposition of most cases is far from simple. ${ }^{75}$ Doctrinal ambiguity and new conceptions of economic theory necessitate that courts wait until after discovery to determine whether the per se rule or the rule of reason should apply. ${ }^{76}$ Even if a per se violation is alleged, parties cannot be sure whether a court will decide that per se analysis is appropriate until voluminous documents are assessed, several experts are consulted, and many facts are developed. ${ }^{77}$ Thus, parties may end up litigating through discovery and absorbing the costs of rule of reason litigation nonetheless. ${ }^{78}$ If only post-discovery rule determinations are possible, the per se rule forfeits the value of its cost-reducing function. ${ }^{79}$

69. See id. at 2295 (Breyer, J., dissenting); Times-Picayune, 345 U.S. at 594 (1953).

70. See Lina M. Khan, The Supreme Court Case That Could Give Tech Giants More Power, N.Y. TIMES (Mar. 2, 2018), https://www.nytimes.com/2018/03/02/opinion/the -supreme-court-case-that-could-give-tech-giants-more-power.html [https://perma.cc/W2P9 -H2NP]. For example, Amazon provides a platform that connects buyers and sellers of goods; Facebook and Google connect users and advertisers; Uber and Lyft facilitate a market between riders and drivers; Apple links app makers with app users; Spotify and Pandora connect musicians and listeners; banks provide platforms for depositors and borrowers; and airports facilitate trade between airlines and travelers. Id.; see also Khan, supra note 18, at 325 (2018) (describing various forms of power possessed by firms that provide two-sided platforms).

71. See Khan, supra note 18. For instance, if Uber instituted an exclusivity agreement prohibiting its drivers from also driving for Lyft, Uber drivers would be anticompetitively harmed. But Uber might be able to escape antitrust scrutiny if it could demonstrate that the other side of the market-riders-were not harmed by the exclusivity agreement. $I d$.

72. AREEDA \& HovenKAMP, supra note 5, 9311 , at 241; see also Crane, Rules Versus Standards, supra note 20, at 83 ("Per se rules of illegality are often vastly overbroad but an open-ended rule of reason approach would create excessive litigation costs and uncertainty.").

73. AREEDA \& HOVENKAMP, supra note 5, ๆ 305, at 68-70.

74. N. Pac. Ry. Co. v. United States, 356 U.S. 1, 5 (1958).

75. See Easterbrook, supra note 45, at 9 ("When everything is relevant, nothing is dispositive.").

76. AREEDA \& HOVENKAMP, supra note 5, ๆ 311, at 241; see also Easterbrook, supra note 45 , at 7 ("We canot condemn so quickly anymore. What we do not condemn, we must study. The approved method of study is the Rule of Reason.").

77. AREEDA \& HovENKAMP, supra note 5, ๆ 311, at 241-42.

78. Id.

79. Id. The Court attempted its own solution to this litigation expense problem by 
Given the dynamism of the interpretive approach Congress prescribed the Sherman Act, a relative lack of clarity and predictability is probably par for the course. ${ }^{80}$ It has been argued, furthermore, that given Sherman Act interpreters' arduous task of applying murky doctrine to highly nuanced facts, a degree of confusion must be tolerated. ${ }^{81}$ But requests for tolerance downplay the judiciary's limited ability to resolve complex economic issues by way of open-ended examinations into the costs and benefits of any particular course of conduct. ${ }^{82}$ The judiciary seems, as a result, to have embraced the invitation to "ramble through the wilds." ${ }^{, 3}$ Clean analytical categories have largely taken a backseat to a post-hoc, factintensive balancing approach. ${ }^{84}$ As a result, the doctrine has become cluttered with "diverse and even contradictory strains," $" 85$ "decisions that now seem blunders," "substantial doctrinal confusion, if not plain error.", 87

The judiciary's failure to appreciate the economics of restraints on trade and the methods by which colluders succeed creates a breeding ground for confusion. ${ }^{88}$ The Supreme Court itself has acknowledged that the judiciary is "ill-equppied and illsuited" to "analyze, interpret, and evaluate the myriad of competing interests and the endless data that [is] brought to bear on such decisions." 89 The reality is that in light of the alarming level of power held by firms wielding new technologies and new

integrating a threshold "triaging" tool, which has asserted its own impact on the deterioration of the dichotomous structure of section 1. See Crane, Rules Versus Standards, supra note 20, at 61 . This preliminary inquiry, often referred to as the "quick look" rule, involves a truncated analysis which is more elaborate than per se examination, but not quite a full-fledged rule of reason analysis. See Cal. Dental Ass'n v. FTC, 526 U.S. 756, 770 (1999) (observing that the basis for "abbreviated or 'quick look' analysis" was formed by the collection of FTC v. Ind. Fed'n of Dentists, 476 U.S. 447 (1986); NCAA v. Bd. of Regents of Univ. of Okla., 468 U.S. 85 (1984); and Nat'l Soc'y of Prof'l Eng'rs v. United States, 435 U.S. 679 (1978)). Needless to say, it is not entirely clear which cases are appropriate for a quick look analysis; plus, even after the quick look, parties may end up litigating under the rule of reason anyway. AREEDA \& HOVENKAMP, supra note 5, ๆ 305, at 73-74.

80. See Baxter, supra note 5, at 671.

81. Id.

82. See Leegin Creative Leather Products, Inc. v. PSKS, Inc., 551 U.S. 877, 916-17 (2007) (Breyer, J., dissenting) ("How easily can courts identify instances in which the benefits are likely to outweigh potential harms? .... [N]ot very easily .... One cannot fairly expect judges and juries in such cases to apply complex economic criteria without making a considerable number of mistakes ....") (emphasis omitted); see also Easterbrook, supra note 45, at 9 ("[J]udges cannot do what such open-ended formulas require.").

83. United States v. Topco Assocs., 405 U.S. 596, 609 n.10 (1972).

84. Crane, Rules Versus Standards, supra note 20, at 51, 58 (describing "the growing inclination toward fulsome review of the facts" and the growing inclination of courts to "reject bright-line rules").

85. BORK, supra note 8 , at 36 .

86. Easterbrook, supra note 45 , at 2.

87. Baxter, supra note 5 , at 671 .

88. See Bork, supra note 8 , at 48 (observing that a judge's responsibility is that of "continually creating and recreating the Sherman Act out of his understanding of economics"); Leslie, supra note 2, at 893, 894. See generally Baye \& Wright, supra note 16.

89. United States v. Topco Assocs., Inc., 405 U.S. 596, 611-12 (1972). 
business models, ${ }^{90}$ the economic analysis required for deciding Sherman Act cases demands more technological and data-driven economic expertise than it once did. ${ }^{91}$

\section{SHOULD WE CALL IN THE EXPERTS?}

Our increasingly modernized economy demands that our regulatory approach be updated in stride. $^{92}$ The gradual influx of microeconomics and post-hoc examination of facts has steadily increased the role economists and industry experts play in antitrust. ${ }^{93}$ Yet, economic theories and microeconomic analyses are not always easily articulated to the judiciary. ${ }^{94}$ More can be done to make Sherman Act regulation a formally expert-driven administrative enterprise rather than a generalist-driven adjudicative one. ${ }^{95}$ A more optimal level of clarity and predictability might be achieved by integrating some level of antitrust agency rulemaking. ${ }^{96}$ This Part briefly considers the idea that an agency rulemaking solution makes the most sense given that Sherman Act interpreters (the judiciary) and enforcers (the FTC and the DOJ) already approximate agency rulemaking to some degree.

\section{A. Approximating Agency Rulemaking}

First, like agencies during notice-and-comment rulemaking, the Court relies on external sources of analytical and empirical information to parse through difficult theoretical arguments. ${ }^{97}$ Because the judiciary is comprised mostly of generalist judges, it must somehow make up for its lack of access to powerful empirical and analytical tools. ${ }^{98}$ The Court cannot simply rely on litigants to do all the heavy analytical lifting; litigants advocate their economic analyses in ways that favor the

90. See Khan, supra note 18 , at 325.

91. See Haw, supra note 9, at 1263.

92. See generally Comment of Fed. Trade Comm'r Rohit Chopra, supra note 27 (outlining the need for an updated antitrust enforcement approach).

93. See Crane, Rules Versus Standards, supra note 20, at 50. ("As antitrust has become de-politicized and de-ideologized, flexible technocratic expertise has replaced legalist conceptualism. Once the stars of the antitrust courtroom, lawyers now play the supporting cast to economists."); Lipsky, supra note 58, at 165 (“[R]apid assimilation of microeconomics into antitrust thinking makes almost every antitrust controversy an exercise in microeconomic analysis.").

94. See, e.g., Baye \& Wright, supra note 16.

95. See Crane, Rules Versus Standards, supra note 20, at 1160 (celebrating antitrust's technocratic shift); Lipsky, supra note 58, at 164 (exploring how antitrust's economic revolution can be advanced to the next stage). But see Harry First \& Spencer Weber Waller, Antitrust's Democracy Deficit, 81 FordHam L. ReV. 2543, 2544 (2013) (criticizing antitrust's technocratic shift as an "unbalanced system [that] puts too much control in the hands of technical experts, moving antitrust enforcement too far away from its democratic roots").

96. See generally Haw, supra note 9.

97. Id. at 1248 .

98. See POSNER, supra note 6, at 107. 
outcomes they seek. ${ }^{99}$ Naturally, then, the Court must often rely on third-party sources of information, such as academic studies and data. ${ }^{100}$

The Court seems to place significant weight on the perspectives of interested parties who participate in antitrust cases as an amicus curiae. ${ }^{101}$ As amici, trade associations, companies, professors, and others offer their own empirical data and perspectives. ${ }^{102}$ Interested parties lobby the Court for a preferred rule much the way these same parties submit comments to administrative agencies. ${ }^{103}$ But under the adjudicative approach, it is difficult to predict how an inexpert court will discriminate between opposing versions of an economic theory. ${ }^{104}$

Leegin, which overturned the Court's century-old ban on RPM, is a good example of the Court's agency rulemaking approximation. ${ }^{105}$ The Leegin Court relied significantly on amicus briefs signed by more than two dozen economists, ${ }^{106}$ which theorized the procompetitive benefits of RPM and offered empirical data highlighting the costs of applying the per se rule to RPM. ${ }^{107}$ The Court cited to the amici's arguments on multiple occasions, ${ }^{108}$ demonstrating that the Court placed some weight on the amici's perspectives, much as an agency would do during noticeand-comment rulemaking. ${ }^{109}$ More recently, in American Express, the majority opinion was littered with citations to secondary sources discussed by amici. ${ }^{110}$ There,

99. Haw, supra note 9, at 1260.

100. See, e.g., Ohio v. Am. Express, 138 S. Ct. 2274, 2295 (2018) (Breyer, J., dissenting) (noting that there is no support in antitrust law for treating a two-sided market as a singular whole).

101. See generally Stephen Calkins, The Antitrust Conversation, 68 ANTITRUST L.J. 625 (2001) (examining the influence of amici in particular cases and noting that "[a]lthough many important antitrust cases were written without benefit of amici . . . amicus participation has helped shape the doctrine we apply every day"). See also Crane, Rules Versus Standards, supra note 20, at 96 (observing that "amicus curiae briefs can exert considerable influence" and that "[a]ffected constituencies frequently attempt to shape antitrust decisions"); Haw, supra note 9 at 1248 (arguing that "help with understanding economic theory and interpreting empirical data on competition . . . comes from amicus briefs" which "often present more economic arguments than the parties' briefs" and which "receive considerable attention from the Court and influence its opinions").

102. Crane, Rules Versus Standards, supra note 20, at 96; Haw, supra note 9, at 1248.

103. See Haw, supra note 9, at 1259; see also Calkins, supra note 101, at 652 ("In fact, amici have long played a key role in addressing the intersection between the per se rule and the rule of reason.").

104. See Lipsky, supra note 58, at 175.

105. See Leegin Creative Leather Prods., Inc. v. PSKS, Inc., 551 U.S. 877 (2007). Rebecca Haw Allensworth also outlines Linkline as a salient example. See Haw, supra note 9, at 1270 (discussing Pac. Bell Tel. Co. v. Linkline Commc'ns., Inc., 555 U.S. 438 (2009)). Other examples outlined by Stephen Calkins include State Oil v. Khan, 522 U.S. 3 (1997); Eastman Kodak Co. v. Image Tech. Servs., Inc., 504 U.S. 451 (1992); and, among others, Continental T.V., Inc. v. GTE Sylvania Inc., 433 U.S. 36 (1977). See Calkins, supra note 101.

106. Haw, supra note 9 , at $1280-84$.

107. Id.

108. Id.

109. Id.

110. See Ohio v. Am. Express Co., 138 S. Ct. 2274, 2285-87 (2018); see also Calkins, supra note 101, at 633 ("[W]hen the Court relies significantly on legal and economics secondary sources discussed by amici . . . it is at least possible that amici made a difference."). 
the Court's reliance on external theories to map out the concept of two-sided markets was clear. And, as in Leegin, where the Court completely departed from precedent, the American Express Court departed from earlier precedent instructing that market analysis should be defined narrowly. ${ }^{111}$

Like the Court, the DOJ approximates certain aspects of formal rulemaking. Guidance documents promulgated by the DOJ bear resemblance to rulemakings but lack the benefits of formal notice and comment. ${ }^{112}$ Take the DOJ's no-poach guidance, for example. ${ }^{113}$ Published in 2016, the no-poach guidance alerted firms that agreements between employers to refrain from recruiting each other's employees would be subject to criminal sanctions. ${ }^{114}$ Prior to 2016 , no-poach agreements were only enforced by civil remedies. ${ }^{115}$ Needless to say, spurred by the possibility of criminal fines or imprisonment, firms have scrambled to ensure compliance. ${ }^{116}$ Even though the no-poach guidance is not a binding policy, ${ }^{117}$ the DOJ has stuck to its word and begun pursuing firms that employ no-poaching agreements. ${ }^{118}$

A major issue with the no-poach guidance is that it announced, almost without notice, a novel enforcement position and a new risk of criminal liability. Yet, interested and effected parties were not afforded a formal opportunity to weigh in. ${ }^{119}$ Of course, whether the Supreme Court will ultimately interpret the Sherman Act such that no-poach agreements fall within the scope of its criminal prohibitions is unclear. ${ }^{120}$ If the Court relies on amicus briefs in determining the criminality of nopoach agreements - briefs which may, for example, parse through theories of competition in low-skilled labor markets - one result may be heightened uncertainty among the governed public over the judiciary's willingness to acquiesce to DOJ enforcement positions that create new per se violations, as well as new criminally enforceable per se violations. The broader consequence: an even more blurred line between the per se rule and the rule of reason.

111. See American Express, 138 S. Ct. at 2274; Times-Picayune Pub. Co. v. United States, 345 U.S. 594, 594 (1953).

112. See, e.g., No-PoACH GuIDANCE, supra note 15.

113. $I d$.

114. Id.

115. $I d$.

116. See, e.g., Corman et al., supra note 15 .

117. See Memorandum from the Attorney Gen. on the Prohibition on Improper Guidance Documents (Nov. 16, 2017), https://www.justice.gov/opa/press-release/file/1012271 /download [https://perma.cc/SY8X-BRFW].

118. See, e.g., James Doubek, 8 Restaurant Chains Agree to End 'No-Poach' Agreements Under Threat of Lawsuit, NPR (Aug. 22, 2018, 3:45 AM), https://www.npr.org/2018/08/22 /640776195/8-fast-food-companies-agree-to-end-no-poach-agreements-under-threat-of -lawsuit [https://perma.cc/24RT-CTX3]; Victoria Graham, Justice Department to Pursue Healthcare 'No-Poach' Cases, Official Says, BloomBerg BNA (May 27, 2018), https://www.bna.com/justice-dept-pursue-n73014476113 [https://perma.cc/D4AZ-Y44B].

119. See No-PoACH GuidanCE, supra note 15.

120. See, e.g., Press Release, U.S. Dep't of Justice, Justice Department Requires Knorr and Wabtec to Terminate Unlawful Agreements Not to Compete for Employees (Apr. 3, 2018), https://www.justice.gov/opa/pr/justice-department-requires-knorr-and-wabtec-terminate -unlawful-agreements-not-compete [https://perma.cc/WEH6-YBW2] (noting the DOJ's decision not to pursue criminal charges against two rail equipment suppliers). 
Clarity and predictability are paramount in a field as impactful and esoteric as antitrust. ${ }^{121}$ To be sure, the text of the Sherman Act is so vague and so broad that it makes sense for the Court to draw on as much information as possible and for the DOJ to provide at least some clarity by way of guidance documents. ${ }^{122}$ But if textual vagueness and judicial inability to perform empirical analyses necessitates reliance on expert input and guidance documents, it makes more sense to let the experts just write the rules in the first place. ${ }^{123}$ Of course, leaving first-instance Sherman Act interpretation in the hands of the judiciary carries some advantages. Such advantages include the ability to "create law with actual facts in sight"; to remain "incremental, adaptive, and flexible"; to "disperse decisionmaking power" horizontally and vertically; and to avoid "agency-capture problems." 124

However, any such advantages can easily be construed as disadvantages as well. For example, dispersing decisionmaking power broadly is not significantly advantageous, if at all, if the decisionmakers lack the requisite expertise. And while an antitrust agency might be captured by industry interests, the judiciary can also be captured by intellectual or attitudinal trends. ${ }^{125}$ For instance, as evidenced by the contemporary predominance of the consumer welfare standard, as opposed to a total welfare or competitive process standard, the Court was arguably "captured" by the Chicago School theories that came to prominence in the 1970 s. ${ }^{126}$

While potential advantages of the adjudicative approach can be debated, the fact remains that the judiciary is unable to produce expert economic analyses on its own and must rely on outside input to solve complex economic issues. ${ }^{127}$ The judiciary is not optimally positioned to resolve disputes over economic competition. ${ }^{128}$ An antitrust agency, on the other hand, could write rules addressing RPM or two-sided markets or no-poach agreements after conducting its own studies and allowing interested parties to weigh in during notice and comment. As a result, the benefits of formal notice-and-comment rulemaking, clarity and predictability among them, might be realized more keenly than under the adjudicative model.

\section{B. DOJ or FTC?}

The difficult question concerns which agency should be authorized to promulgate rules under the Sherman Act. Congress's grant of regulatory authority to the FTC - an independent agency with both adjudicative power and rulemaking authority -reflects Congress's recognition that protecting consumer welfare requires

121. See Comment of Fed. Trade Comm'r Rohit Chopra, supra note 27; Hearings on Competition and Consumer Protection in the 21st Century, supra note 22.

122. See Haw, supra note 9, at 1268.

123. But see Crane, Technocracy, supra note 20, at 1190 (describing the potential advantages the adjudicatory model might have over an administrative model).

124. Id.

125. See Crane, Rules Versus Standards, supra note 20, at 98.

126. See infra text accompanying note 192 .

127. See Haw, supra note 9, at 1263.

128. See Crane, Technocracy, supra note 20, at 1193 (“Adjudication's 'all-or-nothing' structure is ill suited for antitrust ... . [A]ntitrust is about solving modern industrialorganization problems, not about expressing social values or similar democratic functions."). 
specialized decision-making. ${ }^{129}$ Plus, a series of hearings held by the FTC in the fall of 2018 and an expressed willingness to utilize its rulemaking capabilities reflects the sense that clearer and more effective rules are in order. ${ }^{130}$

One issue with the agency solution is that the FTC's Bureau of Competition awkwardly shares regulatory jurisdiction with the DOJ's Antitrust Division, but only the DOJ is authorized to enforce the Sherman Act's criminal provisions. In some ways, this adds to the difficultly faced by firms in predicting what kind of regulatory attention their conduct might invite. Not only are parties required to speculate as to whether their conduct will be subject to per se or rule of reason analysis, they also must speculate whether their cases will be heard by an Article III court or an administrative law judge. Still, the antitrust agencies have investigative abilities and subject matter expertise that the Court does not. ${ }^{131}$

Though the mechanics of the agency solution are beyond the scope of this Note, shifting the authority to interpret the Sherman Act to the FTC or DOJ could facilitate the adoption of clearer, more predictable rules. ${ }^{132}$ Indeed, the judiciary's reliance on amicus briefs in Sherman Act cases and the DOJ's use of nonbinding guidance documents may resemble agency decision-making enough that formalizing Sherman Act notice-and-comment rulemaking makes the most sense. ${ }^{133}$ But apart from the mechanical issues of the agency solution, there might also be some constitutional obstacles. Part III considers whether the vagueness of the Sherman Act's language raises separation of powers and fairness concerns such that, absent a significant legislative update to the Act's language, the agency solution is a moot point.

\section{Constitutional OBjections to the Agency Solution}

To be sure, the Sherman Act's sparse text and accompanying body of doctrine are not viewed across the board as problematic - at least not constitutionally problematic. ${ }^{134}$ The prevailing view is that the Court's interpretive leeway is farreaching, but constitutionally permitted. ${ }^{135}$ Nonetheless, the Act has been called an impermissibly broad delegation of legislative power and an unconstitutionally vague statute. ${ }^{136}$ While it has not been successfully challenged on these grounds since its enactment, ${ }^{137}$ the Act may now be more vulnerable to separation of powers and

129. AREEDA \& HovenKAMP, supra note 5 , \ 302, at 13-15.

130. Hearings on Competition and Consumer Protection in the 21st Century, supra note 22.

131. See PosNer, supra note 6, at 104; Haw, supra note 9, at 1287.

132. See Comment of Fed. Trade Comm'r Rohit Chopra, supra note 27 (arguing that “"[r]ulemaking' often evokes the idea of government imposing some inflexible prescription upon the marketplace" but that "rulemaking would enable the Commission to issue clear rules to give market participants sufficient notice about what the law is and is not, helping ensure that enforcement is predictable").

133. Id.

134. See, e.g., Nash v. United States, 229 U.S. 373 (1913).

135. Id.

136. See, e.g., Oldham, supra note 11, at 320-22.

137. Id. 
vagueness attacks in light of its expanded coverage and the contemporary challenges of regulating competition. ${ }^{138}$

\section{A. Impermissible Vagueness}

The appropriateness of the Act's criminal penalties is not free from scrutiny, although the utility of its criminal penalties is plain enough. ${ }^{139}$ Imprisonment of individual corporate officials surely deters reprehensible conduct in a way that issuing an injunction or dipping into a corporation's treasuries does not. ${ }^{140}$ Yet, on its face, the Act's language does not purport to preclude the possibility that a defendant may be imprisoned after an ex post finding by a jury that his conduct was economically unreasonable - regardless of whether it was morally reprehensible. ${ }^{141}$ If actualized, such a possibility might chill commercial conduct that would be economically beneficial to society and undeserving of the pain and stigma of criminal punishment. ${ }^{142}$ Moreover, laws like the Sherman Act that do not clearly define their prohibitions may, in practical effect, impermissibly delegate fundamental policy questions to adjudicators for ad hoc resolution. ${ }^{143}$

The void-for-vagueness doctrine requires that criminal statutes be "sufficiently explicit to inform those who are subject to it what conduct on their part will render them liable to its penalties." ${ }^{\text {144 }}$ Generally speaking, a statute is unconstitutionally vague if "[persons] of common intelligence must necessarily guess at its meaning and differ as to its application." 145 But the Court does not apply the vagueness doctrine simplistically, and certain considerations may alleviate concerns over an otherwise vague statute. ${ }^{146}$ For example, if the general class of conduct to which a statute is directed falls plainly within the statute's terms, the Court likely will not strike the statute just because marginal cases may raise doubts. ${ }^{147}$

138. Athanasoulis, supra note 29 , at 1289.

139. See, e.g., AREeda \& HovenKamp, supra note 5, $\uparrow 303$, at 43 (“A basic policy dispute about antitrust law concerns the appropriateness of criminal sanctions. The prohibitions of the Sherman Act are, after all, quite vague and general."); Connolly, supra note 43.

140. AREEDA \& HovenKAMP, supra note 5, 9303 , at 44; see also United States v. U.S. Gypsum Co., 438 U.S. 422, 440-41 (1978) ("[T]he behavior proscribed by the Act is often difficult to distinguish from the gray zone of socially acceptable and economically justifiable business conduct.").

141. See Connolly, supra note 43.

142. See Note, The Void-for-Vagueness Doctrine in the Supreme Court, 109 U. PA. L. REV. 67 (1960). Violation of the Sherman Act was punishable as a misdemeanor until it became a felony in 2004. See Antitrust Criminal Penalty Enhancement and Reform Act of 2004, Pub. L. No. 108-237, 118 Stat. 661 (codified as amended in scattered sections of 15 U.S.C.).

143. See Geoffrey R. Stone, Louis M. Seidman, Cass R. Sunstein, Mark V. Tushnet \& Pamela S. Karlan, The First Amendment 119 (5th ed. 2016) (quoting Grayned v. Rockford, 408 U.S. 104, 108-09 (1972)).

144. Connally v. Gen. Constr. Co., 269 U.S. 385, 391 (1926).

145. Id.; see also United States v. Harriss, 347 U.S. 612, 617 (1954) ("The underlying principle is that no [person] shall be held criminally responsible for conduct which he could not reasonably understand to be proscribed.").

146. Anasthoulis, supra note 29, at 1289 n.29.

147. Harriss, 347 U.S. at 618. 
Unlike other criminal statutes, though, the Sherman Act requires an unusual level of interpretation. ${ }^{148}$ This was made especially evident during the decades immediately following the Act's passage, when the Court began to guess at the meaning of its prohibitions. ${ }^{149}$ As discussed in Section I.A, the Court declared that the Act's language does not mean what it actually says: the Court interpreted "every" restraint of trade to mean only "unreasonable" restraints of trade. ${ }^{150}$ Still, to be sure, the judiciary is generally free to shape the character of criminal prohibitions by interpreting statutes against varying factual circumstances. ${ }^{151}$ The judiciary is not, however, permitted to create common law crimes, ${ }^{152}$ even if the harm caused by certain conduct warrants criminal sanctions in the overwhelming majority of cases.

Consider an argument the DOJ once made before the Seventh Circuit: "Since the per se rules define types of restraints that are illegal without further inquiry into their competitive reasonableness . . . . It is as if the Sherman Act read: 'An agreement among competitors to rig bids is illegal. ${ }^{, 153} \mathrm{But}$, in fact, the statute does not read that way. The Sherman Act could include the words "bid-rigging" or "price-fixing" or "no-poach," but it does not. It says nothing about limiting criminal penalties to a single judicially created category of conduct. ${ }^{154}$ It says nothing about criminal intent or categorical unreasonabless. ${ }^{155}$ Such interpretations have instead been worked out by the Court and by litigants-case-by-case, claim-by-claim.

The nature of modern-day commerce and the lack of any substantive legislative updates call into question whether the Act still —if it ever did - sufficiently informs potential defendants of the conduct that could subject them to criminal punishment. ${ }^{156}$ Perhaps the Court's addition of a mens rea element and its distinction between per se and rule of reason have compensated for any lack of fair notice. ${ }^{157}$ Indeed, no void-for-vagueness challenge against the Sherman Act has ever succeeded. ${ }^{158}$ Yet, the Act's coverage of unreasonable restraints of trade has greatly expanded. ${ }^{159}$ No-poaching agreements, for example, were not always considered an inherently unreasonable restraint of trade; once they were considered as such, nopoaching agreements were enforced by civil remedies until the 2016 guidance

148. See AREEDA \& HovenKAMP, supra note 5, ๆ 303. at 40; see also Haw, supra note 9.

149. See, e.g., Standard Oil Co. of New Jersey v. United States, 221 U.S. 1, 62-65 (1911).

150. Id.

151. AREEDA \& HOVENKAMP, supra note 5, ๆ 303, at 45-46.

152. See, e.g., United States v. Hudson \& Goodwin, 11 U.S. (7 Cranch) 32 (1812).

153. United States v. Brighton Bldg. \& Maint. Co., 598 F.2d 1101, 1106 (7th Cir. 1979) (emphasis added) (internal quotations omitted).

154. 15 U.S.C. $\S \S 1-7$ (2012).

155. See Liparota v. United States, 471 U.S. 419, 424 (1985) ("The definition of the elements of a criminal offense is entrusted to the legislature, particularly in the case of federal crimes . . ."); United States v. Bass, 404 U.S. 336, 348 (1971) (“[L]egislatures and not courts should define criminal activity.").

156. See Connolly, supra note 43.

157. But see Charles D. Weller, The End of Criminal Antitrust's Per Se Conclusive Presumptions, 58 ANTITRUST BULL. 665, 668-70 (2013) (arguing that inserting a mens rea element and limiting antitrust crimes to per se violations may not have fixed the Sherman Act's constitutional defects).

158. See, e.g., Nash v. United States, 229 U.S. 373 (1913).

159. Anasthoulis, supra note 29, at 1286; see also AREEDA \& HovENKAMP, supra note 5, ๆ 303, at 45-46; Price Fixing, Bid Rigging and Market Allocation Schemes, supra note 36. 
document declared that they warranted criminal sanctions. ${ }^{160}$ Whether a non-binding guidance document constitutes sufficient notice that no-poach agreements are a crime is highly debatable. But interpretative developments like the no-poach guidance have arguably fashioned unlegislated crimes, signaling that the Act may not provide fair notice. ${ }^{161}$

\section{B. Controversiality of Administrative Crimes}

Another issue implicated by the Sherman Act's criminal arm is that delegating interpretive authority to an antitrust agency may undermine basic philosophies of criminal liability. ${ }^{162}$ Criminal punishment reflects society's contempt for certain conduct, but when a governmental body other than Congress is authorized to promulgate and enforce criminally punishable prohibitions, society's voice is not heard as loudly. ${ }^{163}$ The Sherman Act was written with such generality that delegation to an antitrust agency without meaningfully updated language may do little more than authorize the agency to create controversial administrative crimes. ${ }^{164}$

The Court has hesitated at times over the degree of deference it should afford to administrative crimes. ${ }^{165}$ In Fahey v. Mallonee, for example, the Court postulated that delegation of rulemaking authority "might not be allowable to authorize creation of new crimes." "T66 The Court later signaled in Touby v. United States that "greater congressional specificity [may be] required in the criminal context," but that precedent is unclear on this question. ${ }^{167}$ The Court's hesitancy reflects concerns that

160. No-POACH GuidanCE, supra note 15.

161. But see supra Section I.B. The question of whether certain conduct is "inherently" anticompetitive is not always intuitive. $I d$.

162. Sanford N. Greenburg, Who Says It's a Crime?: Chevron Deference to Agency Interpretations of Regulatory Statutes that Create Criminal Liability, 58 U. PITT. L. REV. 1, 17 (1996) ("Judicial deference to agency interpretations of ambiguous regulatory statutes allegedly undermines the principle that federal crimes must be legislative creations."). See also Richard E. Myers II, Complex Times Don't Call for Complex Crimes, 89 N.C. L. Rev. 1849, 1865 (2011) (contending that the rise of the administrative state has created an overabundance of criminally enforceable administrative regulations).

163. See United States v. Bass, 404 U.S. 336, 348 (1971) ("[L] egislatures and not courts should define criminal activity."); see also Henry M. Hart Jr., The Aims of the Criminal Law, 23 L. \& CONTEMP. Probs. 401, 405 (1958). When a governmental body other than Congress is authorized to promulgate criminally enforceable rules, there is potential for arbitrary deprivations of liberty. Id.; see also Mark D. Alexander, Note, Increased Judicial Scrutiny for the Administrative Crime, 77 CORNELL L. REV. 612, 614 (1992).

164. Greenburg, supra note 162, at 17. ("Judicial deference to agency interpretations of ambiguous regulatory statutes allegedly undermines the principle that federal crimes must be legislative creations.").

165. As with congressional delegations generally, the Court has become more accepting of administrative crimes as time has passed. Compare United States v. Eaton, 144 U.S. 677 (1892), with United States v. Grimaud, 220 U.S. 506 (1911).

166. 332 U.S. 245, 252 (1947).

167. 500 U.S. 160, 166 (1991). At issue in Touby was a provision of the Controlled Substances Act, which authorizes the U.S. Attorney General to deem manufacture, possession, or distribution of particular substances illegal if he or she decides the substance presents an "imminent hazard to the public safety." Id. at 163. Petitioners claimed delegations permitting the Attorney General to define - rather than simply enforce-the criminally punishable 
the power to define crimes - that is, to codify the moral judgements of societyshould belong to Congress, rather than administrative agencies. ${ }^{168}$ While agency administrators are often the top experts in their substantive fields, they are probably not the appropriate arbiters of society's moral persuasion. ${ }^{169}$

Since Touby, the Court has not reconsidered the intelligible principle standard's low barrier in the context of agencies interpreting vague criminal statutes. But the possibility remains open. ${ }^{170}$ At least three of the sitting Justices have since questioned the propriety of administrative crimes, as well as the efficacy of the nondelegation doctrine. ${ }^{171}$ Despite no official condemnation of administrative crimes, the future possibility thereof could stymie a delegation of rulemaking authority to an antitrust agency.

\section{Unguided Agency Authorizations}

Notwithstanding the Sherman Act's dual criminal-civil character, it has long been recognized as a general principle that Congress cannot shift its legislative power to other branches of the federal government. ${ }^{172}$ This principle, referred to as the

conduct should be guided by something more than an intelligible principle. $I d$. at $165-66$. The Court declined to answer this claim in detail because the delegation would "[pass] muster even if greater congressional specificity [were] required in the criminal context." $I d$.

168. Greenburg, supra note 162 , at 17.

169. See Alfred C. Aman Jr., Administrative Law in a Global Era: Progress, Deregulatory Change, and the Rise of the Administrative Presidency, 73 CORNELL L. REV. 1101, 1121 (1988) ("[T] here are no real values experts."); Myers, supra note 162, at 1864.

170. See, e.g., Petition for Writ of Certiorari, Gundy v. United States, No-17-6086 (argued Oct. 2, 2018), http://www.scotusblog.com/wp-content/uploads/2018/02/17-6086-petition.pdf [https://perma.cc/3B72-7H5Q]. As of the writing of this Note, the disposition of Gundy remains to be seen. Id. A major question in the case is whether the Sex Offender Registration and Notification Act impermissibly delegates authority to the Attorney General in violation of the nondelegation doctrine. Id. Petitioner Gundy argued that SORNA is unconstitutional in part because "[t]he Constitution prohibits Congress from delegating its legislative powers, particularly in the criminal context." Brief for Petitioner at 17, Gundy v. United States, No17-6086 (argued Oct. 2, 2018), https:/www.supremecourt.gov/DocketPDF/17/17 -6086/48309/20180525141125861_Brief\%20for\%20Petitioner.pdf [https://perma.cc/4QTT -SXGG]. According to Petitioner Gundy, "Congress has delegated to the Attorney General the authority to define, and determine the scope of, the elements of SORNA's new federal criminal offense," which are "quintessentially legislative powers." Id. at 23. For a general summary of the case, see Mila Sohoni, Argument Preview: Justices Face Nondelegation Challenge to Federal Sex-Offender Registration Law, SCOTUSBLoG (Sept. 25, 2018, 10:11 AM), http:// www.scotusblog.com/2018/09/argument-preview-justices-face-nondelegation-challenge-to -federal-sex-offender-registration-law [https://perma.cc/5A6H-2Z4F].

171. See, e.g., Sessions v. Dimaya, 138 S. Ct. 1204, 1223 (2018) (Gorsuch J., concurring); City of Arlington v. FCC, 569 U.S. 290, 315 (2013) (Roberts, C.J., dissenting); Whitman v. Am. Trucking Ass'n, 531 U.S. 457, 487 (2001) (Thomas, J., concurring); United States v. Nichols, 784 F.3d 666, 671 (10th Cir. 2015) (Gorsuch, J., dissenting).

172. See Mistretta v. United States, 488 U.S. 361, 371-72 (1989); Field v. Clark, 143 U.S. 649, 692 (1892); A.J. Kritikos, Resuscitating the Non-Delegation Doctrine: A Compromise and an Experiment, 82 Mo. L. REV. 441, 442 (2017); see also, e.g., Panama Refining Co. v. Ryan, 293 U.S. 388, 421 (1935) (recognizing that "legislation must often be adapted to complex conditions involving a host of details with which the national legislature cannot deal 
nondelegation doctrine, is integral to the preservation of our tripartite system of government. ${ }^{173}$ Yet, despite its importance, determining how and when to apply the nondelegation doctrine is not an easy task. ${ }^{174}$ The Court struggled early on to draw a workable line between permissible and impermissible delegations. ${ }^{175}$ Even after declaring it universally recognized that Congress cannot delegate legislative power, the Court eventually acquiesced to this line-drawing difficulty after the Great Depression. ${ }^{176}$

The "intelligible principle" standard, by which the Court has traditionally determined whether a delegation offends the separation of powers, is extremely deferential to Congress's need for regulatory assistance. ${ }^{177}$ Under this standard, a congressional delegation will be constitutionally agreeable so long as the enabling legislation contains an explicit and intelligible principle to guide the agency as it exercises the regulatory authority conferred upon it. ${ }^{178}$ Intelligible principles need not be articulated with any serious specificity. For instance, Congress authorized the Securities and Exchange Commission to ensure holding companies' corporate structures do not "unduly or unnecessarily complicate" or "unfairly or inequitably distribute" shareholders' voting power. ${ }^{179}$ Similarly, the Federal Communications Commission was charged with regulating broadcast licensing according to "public interest, convenience, or necessity." 180 The Court held that the intelligible principle standard had been satisfied in both instances. ${ }^{181}$

The text of the Sherman Act may not, to the contrary, contain an ostensible intelligible principle. ${ }^{182}$ The Act broadly prohibits conduct "in restraint of trade" without defining restraint of trade and without mentioning, for example, public

directly").

173. See Kritikos, supra note 172.

174. Id.

175. See Mistretta, 488 U.S. at 415 (Scalia, J., dissenting) ("[W]hile the doctrine of unconstitutional delegation is unquestionably a fundamental element of our constitutional system, it is not an element readily enforceable by the courts."); Wayman v. Southard, 23 U.S. 1, 42-43 (1825) (explaining that deciding the boundary at which to demarcate the permissible from the impermissible requires a delicate inquiry with no clear-cut answers). But see Gary Lawson, Delegation and Original Meaning, 88 VA. L. REv. 327, 395 (2002) (positing that it is no more difficult to draw a line between execution and lawmaking than it is to draw a line between reasonable and unreasonable searches and seizures).

176. See, e.g., Field, 143 U.S. at 692 (1892); see also Kritikos, supra note 172, at 442. Only twice since then has the Court held a delegation unconstitutional. See Whitman, 531 U.S. at 474-75. The court found an unconstitutional delegation in Panama Refining Co. v. Ryan, 293 U.S. 388 (1935), and another in A. L. A. Schechter Poultry Corp. v. United States, 295 U.S. 495 (1935).

177. See J.W. Hampton, Jr. \& Co. v. United States, 276 U.S. 394, 409 (1928); see also NBC v. United States, 319 U.S. 190, 225-26 (1943). Perhaps insignificantly, the Court later added that Congress must also delineate the outer boundaries of the delegated authority. See Am. Power \& Light Co. v. SEC, 329 U.S. 90 (1946).

178. See J.W. Hampton, 276 U.S. at 406.

179. Am. Power \& Light, 329 U.S. at 104.

180. NBC, 319 U.S. at 225-26.

181. Am. Power \& Light, 329 U.S. at 104; NBC, 319 U.S. at 225-26.

182. 15 U.S.C. $\S \S 1-7$ (2012). 
interest, ${ }^{183}$ protection of small businesses, or any other guiding principle. ${ }^{184}$ The Act's few words say nothing about how to determine whether trade has in fact been restrained or when a would-be restraint of trade should be overlooked because of the benefits it confers. ${ }^{185}$ Some would argue that the measuring stick should be whether conduct affects the democratic process; ${ }^{186}$ others would argue the size and structure of firms is the better guidepost. ${ }^{187}$ But because the Act says nothing to that effect, the doctrine has come to represent the Court's struggle to "settle on an intelligible principle of [its] own choosing." "188

During the latter half of the twentieth century the Court settled on the principle articulated by Robert Bork, commonly considered the most influential scholar of modern antitrust theory. ${ }^{189}$ Bork maintained that in framing the Sherman Act broadly, Congress left the courts free to frame subsidiary rules so long as such rules are geared toward the advancement of consumer welfare. ${ }^{190}$ The ultimate goal of the Sherman Act, said Bork, should be to "improve allocative efficiency without impairing productive efficiency so greatly as to produce either no gain or a net loss in consumer welfare." 191 That is, Sherman Act regulation should be executed in a way that ensures societal resources are both produced effectively by firms and expended on tasks consumers value most. ${ }^{192}$

It may be that such a goal, which has guided antitrust jurisprudence since the late $1970 \mathrm{~s},{ }^{193}$ provides an intelligible principle suitable to guide Sherman Act interpreters. ${ }^{194}$ The problem is that Congress did not reference the consumer welfare

183. Id.

184. Id.; see also 1 Phillip E. Areeda \& Herbert Hovenkamp, Antitrust Law 1111 , at 103100 (4th. ed. 2014).

185. 15 U.S.C. $\S \S 1-7$.

186. See, e.g., Maurice E. Stucke, Is Competition Always Good?, 1 J. AnTITRUST ENFORCEMENT 162 (2013); Harry First \& Spencer Weber Waller, Antitrust's Democracy Deficit, 81 FordHAM L. REV. 2543 (2013).

187. See, e.g., Khan, supra note 27 , at 717 (using the "lens of market structure to reveal anticompetitive aspects of Amazon's strategy and conduct").

188. Oldham, supra note 11, at 352 (observing that it is "unclear how or why the courts can function as antitrust lawmakers without any statutorily designated principle . . . to guide their discretion"). But see AREEDA \& HovENKAMP, supra note 184, at 100 ("[T]he judges are not totally at large. Statutory language sets some bounds . . . . And although the [Act's] words may be somewhat elastic in meaning, they are not entirely protean.") (emphasis added).

189. See, e.g., Dylan Matthews, 'Antitrust Was Defined by Robert Bork. I Cannot Overstate His Influence.,' WASH. PosT (Dec. 20, 2012), https:/www.washingtonpost.com/news/wonk /wp/2012/12/20/antitrust-was-defined-by-robert-bork-i-cannot-overstate-his-influence /?noredirect $=$ on\&utm_term $=.2 \mathrm{fd} 5037 \mathrm{~d} 7 \mathrm{a} 9 \mathrm{e}[\mathrm{https}: / /$ perma.cc/C4U4-SDPC].

190. BORK, supra note 8, at 61; Oldham, supra note 11, at 345; Daniel Fisher, Robert Bork, The Man Who Redefined Antitrust, Is Dead At 85, ForBeS (Dec. 19, 2012, 11:44 AM), https:/www.forbes.com/sites/danielfisher/2012/12/19/robert-bork-the-man-who-redefined -antitrust-is-dead-at-85/\#2c95e1ddcad9 [https://perma.cc/SWT5-EUSE] ("Bork explained how antitrust law only makes sense when viewed as a regulatory structure designed to protect consumers from monopolists.").

191. BORK, supra note 8 , at 91.

192. Id.

193. Khan, supra note 27, at 716.

194. But see Khan, supra note 27 , at 737-38 ("[T]he consumer welfare approach to antitrust is unduly narrow and betrays congressional intent, as evident from legislative history 
standard in the Act. And there was no consensus on the Court before 1979 that it should be singularly guided by the goal of maximizing consumer welfare. ${ }^{195}$ Of course, Congress could insert a consumer welfare provision into the Sherman Act. The likelihood of this, however, is low-especially in light of energized calls for a reformulated standard that measures welfare more holistically. ${ }^{196}$ Either way, the Sherman Act's language does not explicitly state a guiding standard at all. Without such, a delegation of interpretive authority to an antitrust agency may run afoul of the nondelegation doctrine.

\section{CONCLUSION}

The Sherman Act, by its vague and sweeping language, is a broad delegation of authority to the Supreme Court. Congress sent us into the wilderness-law students and generalist judges alike. In light of swelling desire for the antitrust laws to be more effective against modern-day competition foes, Congress should update the Sherman Act. The common-law approach has not achieved the stability one would expect of a statute levying hefty criminal sanctions, and the Court appears to approximate agency rulemaking on an increasingly frequent basis. Delegating rulemaking authority to an antitrust agency may be a viable solution. But there are some draw backs - namely constitutional objections to which the Sherman Act may be vulnerable, especially if an agency delegation were not accompanied by some level of additional statutory clarity. Even if the agency solution proves unworkable, Congress should address head-on the growing need for clarity, predictability, and stability, which the Sherman Act significantly fails to provide.

and as documented by a vast body of scholarship.").

195. See Khan, supra note 27, at 718. The "market-structure based understanding of competition" was foundational through the 1960s. Id. Congress was likely concerned more with suppliers' welfare than consumers' when it enacted the Sherman Act. See, e.g., AREEDA \& HovenKAMP, supra note 184, \ 101, at 9-11 ("Although the drafters of the Sherman Act were concerned about injury to consumers, they were significantly more concerned about various kinds of injury to competitors."); Christopher Grandy, Original Intent and the Sherman Antitrust Act: A Re-Examination of the Consumer-Welfare Hypothesis, 53 J. Econ. Hist. 359, 359 (1993).

196. See, e.g., Khan, supra note 27. 